\title{
Minimal effective dose of phosphine to control the cashew root borer, Marshallius bondari Rosado-Neto (Coleoptera: Curculionidae) ${ }^{1}$
}

\author{
Dose mínima efetiva de fosfina no controle da broca-da-raiz do cajueiro, Marshallius \\ bondari Rosado-Neto (Coleoptera: Curculionidae)
}

\author{
Ervino Bleicher ${ }^{2 *}$, Sandra Maria Morais Rodrigues ${ }^{3}$, Quélzia Maria Silva Melo ${ }^{4}$ e Jaeger Holanda Pinho 5
}

\begin{abstract}
The objective of this research was to determine, in field conditions, the minimal of phosphine effective dose for the cashew root borer control. Three experiments were set up at three different periods: August, October and November, 1994, to control the cashew root borer, Marshallius bondari Rosado-Neto (Coleoptera: Curculionidae), in Piaui State, Brazil. One, two, three and six phosphine tablets of three gram each, per plant were tested. In the August essay, phosphine was inefficient to control the borer. In the October essay, control was achieved using as little as 2 tablets per plant and in November with one tablet per plant to control the adult borers in the soil. Higher efficiency was achieved when treatment was applied far away from the last rain, in other words, as soil dries out.
\end{abstract}

Key words - Cashew tree. Insecta. Chemical control.

Resumo - Objetivou-se determinar, em condições de campo, a dose mínima de fosfina para o controle da broca da raiz do cajueiro. Foram instalados 3 experimentos em épocas distintas, sendo o primeiro em agosto, o segundo em outubro e o terceiro em novembro de 1994 para o controle de Marshallius bondari Rosado-Neto (Coleoptera: Curculionidae) em cajueiro, Anacardium occidentale L. no município de Pio IX, Estado do Piauí. Foram testadas 1; 2; 3 e 6 pastilhas de fosfina na forma de fosfeto de alumínio, de 3 gramas cada, por planta. No ensaio conduzido em agosto nenhum tratamento foi eficiente para o controle de brocas adultas no solo. No ensaio instalado em outubro, a fosfina foi eficiente a partir de duas pastilhas por planta e no ensaio de novembro a partir de uma pastilha por planta para o controle de adultos no solo. A eficiência foi tanto maior quanto maior foi o tempo decorrido após a última chuva, estando, portanto, o solo mais seco.

Palavras-chave - Caju. Insecta. Controle químico.

\footnotetext{
* Autor para correspondência

'Recebido para publicação em 01/07/2009; aprovado em 29/03/2010

Pesquisa Financiada pela Embrapa Agroindústria Tropical

${ }^{2}$ Departamento de Fitotecnia, CCA/UFC, Av. Mister Hull, 2.977, Caixa. Postal 12.168, Fortaleza-CE, Brasil, 60.356-001, ervino@ufc.br ${ }^{3}$ Embrapa Algodão, Campina Grande-PB, Brasil, sandra@cnpa.embrapa.br

${ }^{4}$ Embrapa Agroindústria Tropical, Fortaleza-CE, Brasil

${ }^{5}$ Fazenda Capisa, Pio IX-PI, Brasil
} 


\section{Introduction}

Three borers of the genus Marshallius are associated with the cashew tree, Anacardium occidentale L. M. Multisignatus (Boheman) is found in the states of Pará and Amazonas, in Brazil, and in the French Guyana; $M$. Anacardii Lima, is found in the states of Pará, Piauí, Rio Grande do Norte, Paraíba, Rio de Janeiro and Goiás; and M. Bondari Rosado-Neto, in the states of Bahia and Piauí (LIMA, 1979; MARBACK, 1989; ROSADO-NETO, 1989). $M$. bondari is known as root borer, and has been responsible for the death of a high number of plants at Pio IX, State of Piauí. This insect attacks both common and dwarf cashew types. According to Rosado-Neto (1989), females of this species lay their eggs in the trunk close to the soil surface. Larvae hatch and bore tunnels in direction to the roots. The symptom caused by this insect is generally observed during fruiting phase, the dry period of the year, when, apparently healthy plants show complete leaf dryness in a very short time. This symptom is known as "instantaneous death with leaf retention". When plants show this symptom the root system is already completely destroyed. The larvae are mostly active in the roots during raining season, and at the end of this season, when the late instars are found. At the beginning of the dry season it is observed that a few completely developed larvae, pupas, and then adults remain inside a soil-debris chamber up to the beginning of the next raining season, when moisture softens the ground, allowing adult emergency. In the dry season this pest is vulnerable, due to its immobility. Plants showing "death with leaf retention" symptom are indicative of the insect localization, this is the ideal time for the pest control, and so lowering the potential spread of the insect, by using spot treatment with minimal adverse side effects.

Up to now the only control measure listed is the cutting and burning of attacked plants (CARVALHO et al., 1972). There are many references dealing with the use of phosphine to control insects of stored cereals, but only a few using phosphine to control soil insects, and those mainly to termites control (MELO FILHO; VEIGA, 1997). In a preliminary trial, Bleicher et al. (1995) found that the use of nine, three gram tablets of phosphine $\left(\right.$ Gastoxin $\left.^{\circledR}\right)$, introduced in three holes in the ground at the depth of $40 \mathrm{~cm}$, around and $30 \mathrm{~cm}$ away from the tree, presented $97 \%$ efficacy. The purpose of this research was to determine, in field conditions, the minimal effective dose for the cashew root borer control.

\section{Material and methods}

Three trials were set up in different periods of the year, aiming to control the $M$. bondari by the use of phosphine tablets, in a 4-year dwarf type cashew, at CAPISA farm, located at Pio IX, state of Piauí, Brazil.
The same treatments were used in all trials, as follows: absolute check (control); the use of one, two, three and six, 3 gram phosphine tablets (Gastoxin ${ }^{\circledR}$ : Aluminum phosphid $\left.\left(\mathrm{Al}_{3} \mathrm{PH}_{3}\right)-57 \% \mathrm{p} / \mathrm{p}\right)$, introduced in the ground at the depth of $40 \mathrm{~cm}$, by the use of an iron rod of $1.9 \mathrm{~cm}$ in diameter, at a distance of $30 \mathrm{~cm}$ from the attacked plant. When using two tablets, they were introduced one at each side of the plant. In the treatment using 3 and 6 tablets, they were equally distributed in three holes around the plant, one or two tablets, according to treatments having three or six tablets, respectively. After tablets introduction, the holes were covered with soil.

All trials used the same methodology, being the first initiated on August $15^{\text {th }}$, the second on October $7^{\text {th }}$, and the third on November $22^{\text {nd }}, 1994$. In the August and October trials, 10 plants were used per treatment and 8 plants in the November trial. Plants with symptom were selected by chance in the field.

Evaluations were performed on September $25^{\text {th }}$, November $16^{\text {th }}$ and December $9^{\text {th }}$, for the first, second and third trials, respectively. Evaluation consisted of pulling out the plants, sifting the soil around the roots and counting dead and alive $M$. bondari adults on each plant.

Counting adults was chosen due to the fact that in the second semester of the year, the dry season, almost all insects are in this phase, in a quiescent situation, inside the soil-debris chamber, waiting for the next raining season, which promotes condition for soil emergence.

From the plants initially selected, some were discharged, because they showed no insect. This procedure was employed because it was not known if plants showing "death with leaf retention" symptom were related to the root borer or other factors. So, the number of replicates (plants) for each treatment was unequal, being suggested for this case the use of a completely random design with unequal replicates (R). Analysis was based on alive, dead insects and percentage of adult's survival, computed for each plant. In this research only plants that showed dead or alive insects were used as experimental units. Means were separated by Tukey's test at 5\% probability.

\section{Results and discussion}

The results showed on Tables 1, 2 and 3, indicate that all three variables used (alive, dead insects and survivorship) in statistical analysis presented a similar pattern of dose-response, but survivorship presented a coefficient of variance (CV) similar or lower than other parameters on all three trials. This is because there was no idea of the densities present in each plant, attributed at random to treatments, and plants with higher or lower 
number could be used in treatment yielding in this case a higher $\mathrm{CV}$ for alive and dead insects. By calculating percentage of survivors and using those data for analysis, the variation among treatments was supposed to decrease, so, discussion is based on survivorship. In the August trial, phosphine was not effective against root borer, even for the highest number of tablets used (Table 1). According to Andrei (2005), phosphine gives best results in dry soil; excessive soil moisture breaks down more rapidly their molecules, and restricts diffusion of gas in soil, preventing it from reaching all root system. Rain records for the area were: January $=140.5 \mathrm{~mm}$; February $=88.5 \mathrm{~mm}$; March $=28.0 \mathrm{~mm}$; April $=107.0 \mathrm{~mm}$; May $=100.0 \mathrm{~mm}$, with the last precipitation occurring on the $21^{\text {st }}$ day of this month. This rain profile could explain the failure of phosphine trial of August, if one takes Andrei's (2005) information in account. On the other hand, in the trial initiated in October (Table 2), far away from the last rain, it was observed that two phosphine tablets were efficient to adult control. On the November trial (Table 3), results were even better, where only one tablet permitted only $7.5 \%$ survivorship, supporting so the hypothesis that as soil

Table 1 - Mean number of alive, dead insects and percentage of survivors per plant observed on August trial. Pio IX, PI

\begin{tabular}{|c|c|c|c|c|c|c|c|}
\hline \multirow{2}{*}{$\frac{\text { Numbers of tablets }}{0}$} & \multirow{2}{*}{$\begin{array}{c}\text { Experimental Units (R) } \\
9\end{array}$} & \multicolumn{2}{|c|}{ Alive insects $^{1 /}$} & \multicolumn{2}{|c|}{ Dead insects $^{1 /}$} & \multicolumn{2}{|c|}{ Percentage of Survivors $^{2 /}$} \\
\hline & & 23.2 & $a^{3 /}$ & 0.9 & $a^{3 /}$ & 96.31 & $a^{3 /}$ \\
\hline 1 & 7 & 11.2 & $\mathrm{a}$ & 3.7 & $\mathrm{a}$ & 72.26 & $\mathrm{a}$ \\
\hline 2 & 4 & 7.0 & $\mathrm{a}$ & 1.0 & $\mathrm{a}$ & 87.50 & $\mathrm{a}$ \\
\hline 3 & 4 & 19.5 & $\mathrm{a}$ & 3.5 & $\mathrm{a}$ & 84.76 & $\mathrm{a}$ \\
\hline 6 & 8 & 15.3 & $\mathrm{a}$ & 5.8 & $\mathrm{a}$ & 72.67 & $\mathrm{a}$ \\
\hline $\mathrm{CV}$ & & \multicolumn{2}{|c|}{52.33} & \multicolumn{2}{|c|}{81.15} & \multicolumn{2}{|c|}{32.91} \\
\hline
\end{tabular}

1/2/ For analysis the data were transformed by de formula $\sqrt{X+0.5} \frac{1}{2}$ and arch $\sin \sqrt{X+0.5} \frac{2}{2} ; \frac{3}{2}$ Equal letters in same columns did not differ at 0.05 of significance by Tukey's test

Table 2 - Mean number of alive, dead insects and percentage of survivors per plant observed on October trial. Pio IX, PI

\begin{tabular}{cccccccc}
\hline Numbers of tablets & Experimental Units(R) & \multicolumn{2}{c}{ Alive insects $^{1 /}$} & \multicolumn{2}{c}{ Dead insects $^{1 /}$} & \multicolumn{3}{c}{ Percentage of Survivors $^{2 /}$} \\
\hline 0 & 7 & 26.6 & $\mathrm{a}^{3 /}$ & 1.7 & $\mathrm{a}^{3 /}$ & 93.94 & $\mathrm{a}^{3 /}$ \\
1 & 5 & 56.2 & $\mathrm{a}$ & 13.0 & $\mathrm{ab}$ & 81.21 & $\mathrm{~b}$ \\
2 & 7 & 0.1 & $\mathrm{~b}$ & 16.0 & $\mathrm{~b}$ & 0.88 & $\mathrm{c}$ \\
3 & 10 & 1.0 & $\mathrm{~b}$ & 22.5 & $\mathrm{~b}$ & 4.26 & $\mathrm{c}$ \\
6 & 7 & 0.0 & $\mathrm{~b}$ & 23.7 & $\mathrm{~b}$ & 0.00 & $\mathrm{c}$ \\
\hline $\mathrm{CV}$ & \multicolumn{2}{c}{87.61} & & 52.23 & & 59.05 \\
\hline
\end{tabular}

${ }^{1 / 2}$ /For analysis the data were transformed by de formulae $\sqrt{X+0.5} \frac{1 /}{}$ and $\operatorname{arch} \sin \sqrt{X+0.5} \frac{2}{2} ; 3 /$ Equal letters in same columns did at no differ at 0.05 of significance by Tukey's test

Table 3 - Mean number of alive, dead insects and percentage of survivors per plant observed on November trial. Pio IX, PI

\begin{tabular}{cccccccc}
\hline Numbers of tablets & Experimental Units(R) & \multicolumn{2}{c}{ Alive insects $^{1 /}$} & \multicolumn{2}{c}{ Dead insects $^{1 /}$} & \multicolumn{2}{c}{ Percentage of Survivors $^{2 /}$} \\
\hline 0 & 8 & 16.5 & $\mathrm{a}^{3 /}$ & 1.9 & $\mathrm{a}^{3 /}$ & 89.80 & $\mathrm{a}^{3 /}$ \\
1 & 6 & 1.0 & $\mathrm{~b}$ & 12.3 & $\mathrm{ab}$ & 7.50 & $\mathrm{~b}$ \\
2 & 5 & 0.0 & $\mathrm{~b}$ & 12.2 & $\mathrm{ab}$ & 0.00 & $\mathrm{~b}$ \\
3 & 4 & 3.2 & $\mathrm{ab}$ & 40.0 & $\mathrm{~b}$ & 7.34 & $\mathrm{~b}$ \\
6 & 5 & 0.0 & $\mathrm{~b}$ & 45.2 & $\mathrm{~b}$ & 0.00 & $\mathrm{~b}$ \\
\hline $\mathrm{CV}$ & \multicolumn{2}{c}{124.35} & 51.93 & & 84.71 \\
\hline
\end{tabular}

$1 / 2 /$ For analysis the data were transformed by de formulae $\sqrt{X+0.5} \frac{1 /}{}$ and $\operatorname{arch} \sin \sqrt{X+0.5} \stackrel{2}{2} ; \underline{3}$ Equal letters in same columns did at no differ at 0.05 of significance by Tukey's test 
dries out, the control of the root borer by use of phosphine is better. Besides those cited, no other reference was found showing failure of phosphine against soil insects with the exception of Melo Filho e Veiga (1997) who found differences of their work compared to others when working with termites. These authors attributed the misleading results to different sizes of termite nests used by different authors. Soil moisture conditions were not mentioned in this research.

Supported by the literature references and principally by the results of this research, it may be concluded that the use of phosphine tablets for the root borer control should be performed the further possible from the last rain, but before the raining season initiates. As a hot spot management, it is suggested two 3 gram tablets for the insect control. This amount is lower than that recommended by Andrei (2005) to control coffee root scale, where 9 tablets are used, distributed in 3 holes 20 $\mathrm{cm}$ from plant trunk.

\section{Acknowledgement}

To the Caucaia Agropecuaria S.A. (CAPISA) for the facilities, to José Wellington Araújo Pedrosa for the logistic support, and for the Casa Bernardo Ltda, that provided phosphine (Gastoxin ${ }^{\circledR}$ pastilha). This research was supported by Embrapa Agroindústria Tropical through the project grant no. 07.0.94.022.05.

\section{References}

ANDREI, E. Compêndio de Defensivos Agrícolas. 7. ed. São Paulo: Andrei Editora Ltda, 2005. 1141 p.

BLEICHER, E. et al. Controle químico da broca da raiz do cajueiro, Marshallius bondari Rosado-Neto, 1989 (Col.: Curculionidae). Fortaleza: EMBRAPA-CNPAT, 1995. 2p. (Pesquisa em Andamento, 15).

CARVALHO, M. B.; ARRUDA, E. C.; OLIVEIRA, M. H. C. C. de. Marshallius sp. (Coleoptera: Curculionidae), nova praga do cajueiro no município de Gravatá, Pernambuco. Anais do Instituto de Ciências Biológicas, v. 02, n. 02, p. 7-12, 1972

LIMA, V. O. A. Contribuição ao estudo de Marshallius anacardii sp. n., praga do cajueiro em Pernambuco (Coleoptera: Curculionidae). Anais da Universidade Federal Rural de Pernambuco, v. 04, p. 115-148, 1979.

MARBACK, G. L. C. Uma nova espécie de Marshallius (Coleoptera: Curculionidae) atacando cajueiro na Bahia. Anais da Sociedade Entomológica do Brasil, v. 18, n. 02, p. 417-418, 1989.

MELO FILHO, R. M.; VEIGA, A. R. S. L. Eficiência da fosfina no controle do cupim de montículo, Nasutitermis sp. (Isoptera: Termitidae) em cana-de-açucar. Anais da Sociedade Entomológica do Brasil, v. 26, n. 01, p. 21-25, 1997.

ROSADO-NETO, G.H. Marshallius bondari, a new species of Hylobiini (Coleoptera: Curculionidae) damaging cashew (Anacardium occidentale L.) in Bahia State, Brazil. Revista Brasileira de Zoologia, v. 06, n. 03, p. 517-522. 1989. 